\title{
The role of chemokines and chemokine receptors in eosinophil activation during inflammatory allergic reactions
}

S.H.P. Oliveira ${ }^{1}$ and N.W. Lukacs ${ }^{2}$

\section{Correspondence \\ S.H.P. Oliveira \\ Departamento de Ciências Básicas \\ Faculdade de Odontologia de Araçatuba \\ Rua José Bonifácio, 1193 \\ 16015-050 Araçatuba, SP \\ Brasil \\ Fax: +55-18-624-4890 \\ E-mail: shpoliv@foa.unesp.br}

Publication supported by FAPESP.

Received May 8, 2003

Accepted July 4, 2003
'Departamento de Ciências Básicas, Faculdade de Odontologia de Araçatuba, Universidade Estadual Paulista, Araçatuba, SP, Brasil

${ }^{2}$ Department of Pathology, University of Michigan Medical School, Ann Arbor, MI, USA

\begin{abstract}
Chemokines are important chemotactic cytokines that play a fundamental role in the trafficking of leukocytes to sites of inflammation. They are also potent cell-activating factors, inducing cytokine and histamine release and free radical production, a fact that makes them particularly important in the pathogenesis of allergic inflammation. The action of chemokines is regulated at the level of agonist production and processing as well as at the level of receptor expression and coupling. Therefore, an analysis of the ligands must necessarily consider receptors. Eosinophils are target cells involved in the allergic inflammatory response since they are able to release a wide variety of mediators including $\mathrm{CC}$ and $\mathrm{CXC}$ chemokines and express their receptors. These mediators could damage the airway epithelial cells and might be important to stimulate other cells inducing an amplification of the allergic response. This review focuses on recently emerging data pertaining to the importance of chemokines and chemokine receptors in promoting eosinophil activation and migration during the allergic inflammatory process. The analysis of the function of eosinophils and their chemokine receptors during allergic inflammation might be a good approach to understanding the determinants of asthma severity and to developing novel therapies.
\end{abstract}

Chemokines are a large family of cytokines that play a highly important role in orchestrating the exquisitely organized and regulated movement of cells to specific locations within the body. There are large repertoires of chemokine receptors expressed in different cell types. In addition, chemokines promote leukocyte migration and are potent cell activators $(1,2)$. After binding to their receptors on neutrophils, eosinophils, basophils, mast cells and other cells, chemokines elicit granule exocytosis, oxidative burst with
Key words

- Chemokines

- Chemokine receptors

- Allergic inflammation

- Eosinophil the release of superoxide, and nitric oxide release, and can affect gene expression, proliferation, homeostasis and apoptosis (3). Because chemokines are able to attract different cell types, they have been shown to mediate inflammatory tissue destruction in a wide variety of human diseases, such as rheumatoid arthritis, myocardial infarction, adult respiratory distress syndrome and asthma (47). Nowadays, investigating the intracellular mechanisms involved in chemokine-activated cells or creating chemokine receptor antago- 
nists represents an important approach to controlling these specific pathologies.

Chemokines are 8-12-kDa heparin-binding proteins that are rich in basic amino acids and contain conserved cysteine motifs. The latter are involved in the formation of essential disulfide bonds located between the first and third and the second and fourth cysteines in the vicinity of the $\mathrm{N}$-terminus of the protein, thereby defining four structural motifs: CXC, CC, C and CX3C (8). The chemokine nomenclature has been in place since 1996 and has been officially endorsed by the Nomenclature Committee of the International Union of Pharmacological Reviews (2000, 52: 145-176). In an attempt to clarify the complex nomenclature associated with chemokines, Drs. Yoshie and Zlotnik have devised a systematic nomenclature paralleling that of the receptor nomenclature system (8). The chemokine Nomenclature Sub-Committee of the Nomenclature Committee of the International Union of Immunological Societies has considered this system and recommended its adoption by IUIS/WHO (Tables 1 and 2).

The chemokine receptors exert most of their biological effects by binding to a large family of $\mathrm{G}_{\mathrm{i}}$-protein-coupled seven-transmembrane receptors leading to activation of multiple intracellular signaling pathways (9). Redundancy exists in the signaling of chemokines through chemokine receptors because many chemokines bind to more than one

Table 1. CC receptor family, CC chemokine ligands and biological function.

\begin{tabular}{|c|c|c|}
\hline $\begin{array}{l}\text { CC chemokine } \\
\text { receptors }\end{array}$ & CC chemokine ligands & Biological function \\
\hline CCR1 & $\begin{array}{l}\text { MIP-1 } \alpha, \text { RANTES, MCP-2, }-3, \\
\text { HCC-1/MIP-1 } \delta \text { (CCL3, CCL5, CCL8, CCL7, } \\
\text { CCL14, CCL15) }\end{array}$ & $\begin{array}{l}\text { Eosinophil and monocyte migration, } \\
\text { decreased Th2 cytokines and airway } \\
\text { remodelling. Antiviral activity. }\end{array}$ \\
\hline CCR2 & $\begin{array}{l}\text { MCP-1, -2, -3, -4, -5 (CCL2, CCL8, CCL7, } \\
\text { CCL13, CCL12) }\end{array}$ & $\begin{array}{l}\text { Monocyte, lymphocyte and basophi } \\
\text { recruitment. Mast cell degranulation/ } \\
\text { activation. }\end{array}$ \\
\hline CCR3 & $\begin{array}{l}\text { Eotaxin, }-2,-3, \text { RANTES, MIP-1 } \alpha, \text { MCP-2, }-3,-4 \\
\text { (CCL11, CCL24, CCL26, CCL5, CCL3, CCL8, } \\
\text { CCL7, CCL13) }\end{array}$ & $\begin{array}{l}\text { Eosinophil/mast cell chemotaxis/ } \\
\text { activation. Eosinophil, basophil and } \\
\text { Th2 cell recruitment. }\end{array}$ \\
\hline CCR4 & TARC, MDC (CCL17, CCL22) & $\begin{array}{l}\text { Th2 cell, monocyte recruitment, } \\
\text { dendritic cell recruitment. }\end{array}$ \\
\hline CCR5 & $\begin{array}{l}\text { RANTES, MIP-1 } \alpha, \text { MIP-1ß, MCP-2, }-4 \text {, } \\
\text { HCC-1 (CCL5, CCL3, CCL4, CCL8, CCL13, } \\
\text { CCL14) }\end{array}$ & $\begin{array}{l}\text { Th2 cell, macrophage recruitment. } \\
\text { Decreased eosinophilia and airway } \\
\text { hyperreactivity. }\end{array}$ \\
\hline CCR6 & MIP-3 $\alpha(C C L 20)$ & $\begin{array}{l}\text { Decreased eosinophilia, airway } \\
\text { hyperreactivity and lung IL-5. }\end{array}$ \\
\hline CCR7 & MIP-3ß, 6Ckine (CCL19, CCL21) & NK cell recruitment. \\
\hline CCR8 & $\begin{array}{l}\text { I-309, TCA-3 (mouse), TARC, HCC-4 (CCL1, } \\
\text { CCL17, CCL16) }\end{array}$ & $\begin{array}{l}\text { Th2 recruitment, smooth muscle cell } \\
\text { contraction, decreased eosinophilia } \\
\text { and serum IL-5. }\end{array}$ \\
\hline CCR9 & TECK (CCL25) & T-cell recruitment. \\
\hline CCR10 & Eskine, MIP-3 $\alpha, 6$ Ckine (CCL27, CCL20, CCL19) & T-cell recruitment. \\
\hline CCR11 & $\begin{array}{l}\text { MIP-3ß, 6Ckine, TECK, MCP-1, }-2,-3,-4,-5 \\
\text { (CCL19, CCL21, CCL25, CCL2, CCL8, CCL7, } \\
\text { CCL13, CCL12) }\end{array}$ & Monocyte recruitment. \\
\hline
\end{tabular}


chemokine receptor, and many chemokine receptors bind more than one chemokine (Tables 1 and 2).

The G-protein receptor ligation involves activation of the heterotrimeric $\mathrm{G} \alpha / \mathrm{B} \gamma \mathrm{com}$ plex that is responsible, when activated, for different cell functions. For example, the stimulation of chemotaxis by a chemokine requires functional coupling of the receptor to $\mathrm{G \alpha}_{\mathrm{i}}$, since migration is completely inhibited by treatment of the cells with pertussis toxin. However, $G \alpha_{i}$ itself appears not to be necessary for cell migration. The essential step is the release of the heterotrimeric Gprotein $B \gamma$ subunits from $G \alpha_{i}$ and the $G_{i-}$ protein-coupled receptor (10). It was shown that only $B \gamma$ subunits released from $G_{i^{-}}$ coupled receptors, but not those released from $\mathrm{G}_{\mathrm{s}^{-}}$or $\mathrm{G}_{\mathrm{q}}$-coupled receptors, could mediate cell migration (11).

The G-protein effector activation often modifies the concentrations of a second messenger and involves the signal transduction machinery. Most chemokines share the abil- ity to bind to chemokine receptors that trigger these downstream cascades, rapidly activating phosphoinositide-specific phospholipase $C-\beta_{2}\left(\right.$ PLC- $\left.\beta_{2}\right)$ and PLC- $\beta_{3}$ isoenzymes, which lead to inositol-1,4,5-triphosphate formation and to a transient rise in the concentration of intracellular free calcium $\left(\mathrm{Ca}^{2+}\right)$. This pathway has been widely used to test the responsiveness of chemokine receptors to different chemokines (12). In neutrophils of mice that lack the genes encoding PLC- $\beta_{2}$ and PLC- $\beta_{3}$, the chemokine-induced calcium elevation is fully suppressed, which supports the conclusion that PLC $-\beta_{2}$ and PLC- $\beta_{3}$ are the sole PLC isoforms that are activated by chemokines in immune cells (13).

Several other chemokines have been shown to inhibit adenylate cyclase and to activate mitogen/extracellular signal-regulated kinase (MEK)-1 and/or extracellular signal-regulated kinase (ERK)-1/2. In addition, these responses stimulate tyrosine phosphorylation of focal adhesion complex components and activate nuclear factor- $\kappa \mathrm{B}(\mathrm{NF}-$

\begin{tabular}{|c|c|c|}
\hline $\begin{array}{l}\text { CX chemokine } \\
\text { receptors }\end{array}$ & CXC chemokine ligands & Biological function \\
\hline CXCR1 & $\begin{array}{l}\text { IL-8, ENA-78, GCP-2 (CXCL8, } \\
\text { CXCL5, CXCL6) }\end{array}$ & $\begin{array}{l}\text { Neutrophil chemotaxis and functional } \\
\text { modulation. }\end{array}$ \\
\hline CXCR2 & $\begin{array}{l}\text { IL-8, NAP-2, ENA-78, GRO } \alpha, \text { GROß, } \\
\text { GRO } \gamma \text { (CXCL8, CXCL7, CXCL5, CXCL1, } \\
\text { CXCL2, CXCL3) }\end{array}$ & $\begin{array}{l}\text { Neutrophil chemotaxis and functional } \\
\text { modulation. }\end{array}$ \\
\hline CXCR3 & $\begin{array}{l}\text { Mig, IP-10, I-TAC (CXCL9, } \\
\text { CXCL10, CXCL11) }\end{array}$ & $\begin{array}{l}\text { Attraction of Th1 cells, activated eosinophils; } \\
\text { allograft rejection. }\end{array}$ \\
\hline CXCR4 & SDF-1 (CXCL12) & $\begin{array}{l}\text { Reduction of tissue eosinophil recruitment } \\
\text { and airway hyperreactivity, B cell } \\
\text { responses, stem cell homing. }\end{array}$ \\
\hline CXCR5 & BCA-1 (CXCL13) & $\begin{array}{l}\text { Formation of B cell compartment; effector } \\
\text { of T-cell generation. Activated CD } 4^{+} \text {T-cell. }\end{array}$ \\
\hline CXCR6 & CXCL16 & Activated T-cell. \\
\hline CX3CR1 & Fractalkine, neurotactin & $\begin{array}{l}\text { Microglia expression, renal inflammation, } \\
\text { vascular injury. }\end{array}$ \\
\hline XCR1 & Lymphotactin $\alpha$ & Fungal infection, mast cell response. \\
\hline XCR2 & Lymphotactin B & $?$ \\
\hline
\end{tabular}


$\kappa \mathrm{B})$ as well as signal transducer and activator of transcription 1 (STAT1) and STAT3 $(14,15)$. Thus, chemokines can couple to distinct signaling pathways that have been demonstrated to mediate not only migration, but also cell growth and transcriptional activation.

One particular signaling pathway, namely that controlled by lipid kinase phosphoinositide 3-kinase (PI3K), has been the focus of much attention with respect to its activation by chemokine receptors and the role it plays in regulating cell migration. PI3Ks are a family of proteins that catalyze the phosphorylation of the 3-OH position of the inositol head group of phosphoinositide lipids, phosphatidylinositol (PtdIns), phosphatidylinositol (4) phosphate [PtdIns(4)P] and phosphatidylinositol $(4,5)$ bisphosphate [PtdIns $\left.(4,5) \mathrm{P}_{2}\right]$. This results in the formation of PtdIns(3)P, PtdIns(3,4) $\mathrm{P}_{2}$ and PtdIns $(3,4,5) \mathrm{P}_{3}$, respectively, collectively termed 3 '-phosphoinositide lipids (16). PI3K is considered to be one of the direct substrates of heterotrimeric G-protein $B \gamma$ subunit activation that generate lipid second messenger molecules, resulting in the activation of multiple intracellular signaling cascades. These events regulate a broad array of cellular responses, including survival, activation, differentiation and proliferation, and are now recognized as playing a key role in a number of physiological and pathophysiological processes in the lung (17).

PI3K has been shown to be a key regulator of both neutrophil recruitment and activation. In mice lacking the catalytic subunit of the myeloid restricted PI3K- $\gamma$, neutrophil migration to the inflamed peritoneum was severely compromised $(18,19)$. The role of $\mathrm{PI} 3 \mathrm{~K}$ in eosinophil degranulation is not known, but these enzymes are required for activation of the eosinophil NADPH oxidase complex (20).

In eosinophils, eotaxin (CCL11), a CC chemokine that binds CCR3, induces degranulation and chemotaxis through the acti- vation of ERK-2 (a downstream molecule from p42/44 mitogen-activated protein kinases, MAPK) and p38 MAPK (21). However, p38 MAPK plays a greater role than ERK-2 in eosinophil differentiation and macrophage inflammatory protein $1 \alpha$ (MIP- $1 \alpha$, CCL3) production by eosinophils (22). Interestingly, MIP-1ß (CCL4) and T-cell activation gene 3 (TCA-3, CCL1) (CCR5 and CCR8 ligands) induce eosinophil chemotaxis by a $\mathrm{G \alpha}_{\mathrm{i}}$-independent mechanism, because the migration was not inhibited by treatment of the cells with pertussis toxin (Oliveira SHP, unpublished data). Thus, different pathways may be used by eosinophils to carry out their functions.

\section{Chemokines, eosinophils and asthma}

Bronchial asthma is a chronic inflammatory disorder characterized by airway inflammation and infiltration by eosinophils, neutrophils and T lymphocytes (23-25). Furthermore, there is a mass of evidence showing that the severity of the disease depends on eosinophil accumulation and activation within the airways (25-27). Eosinophils contain a number of products that when released directly cause mucosal injury and contribute to the disturbances in lung physiology. These products include major basic protein, eosinophil cationic protein, eosinophil-derived neurotoxin, and eosinophil peroxidase, in addition to oxygen and nitrogen metabolites. In addition, eosinophils generate lipid mediators, including platelet-activating factor, leukotrienes $\mathrm{B}_{4}$ and $\mathrm{C}_{4}$, cytokines and chemokines that are able to activate eosinophils, other leukocytes, and structural cells. In this cascade of events, structural cells release more chemotactic factors such as chemokines and leukotriene $\mathrm{B}_{4}$ that create a more intense inflammatory response (28-30).

The evidence suggests that recruitment of eosinophils into the site of inflammation is a multistep process, involving leukocyteendothelial interactions through adhesion 
molecules and local generation of chemotactic agents that direct cell migration from the vascular compartment into the inflamed airways (1).

For many years, research has been focussed on the mechanisms of activation and recruitment of eosinophils into the airways in asthmatic patients or in animals used as experimental models. Recently, chemokines have been implicated in contributing to allergic disorders, such as asthma (31-33). These chemokines seem to be related to the severity of asthmatic inflammation and reactive airway response.

Chemokines, such as RANTES (CCL5, regulated on activation, normal T-cell expressed and secreted), MIP-1 $\alpha$ (CCL3) and monocyte chemoattractant protein 5 (MCP5, CCL12) are upregulated early after allergen challenge, but one cannot easily demonstrate a correlation between this upregulation and the recruitment of defined leukocyte subsets (34). In contrast, the kinetics of production of eotaxin (CCL11), MCP-1 (CCL2), monocyte-derived chemokine (MDC, CCL22) and thymus- and activationregulated chemokine (TARC, CCL17) shows a good correlation with the recruitment of specific leukocyte subsets expressing the receptors for these chemokines (35-37).

In studies using animal models of allergic airway inflammation, the neutralization of either MIP- $1 \alpha$ (CCL3) or RANTES (CCL5), but not MCP-1 (CCL2), significantly reduced the intensity of the eosinophil recruitment to the lung and airway during the allergic airway response. In contrast, neutralization of MCP-1 (CCL2) significantly reduced total leukocyte migration. Further examination of the effect of MCP-1 (CCL2) depletion indicated that both CD4+ and CD8+ lymphocyte subsets were decreased. Depletion of MCP-1 (CCL2) significantly reduced the airway hyperreactivity to near control levels, whereas depletion of MIP-1 $\alpha$ (CCL3) or RANTES (CCL5) did not affect the intensity of airway hyperreactivity. These data suggest that multiple $\mathrm{CC}$ chemokines are involved in the recruitment of the particular leukocyte populations during the allergic process (38).

Eotaxin (CCL11), the first CC chemokine showing the ability to selectively recruit eosinophils, has drawn most attention from researchers studying allergic responses. Eotaxin (CCL11) was first discovered in the bronchoalveolar lavage fluid of guinea pigs after an allergen challenge (39). It has since been cloned in humans and mice, and appears to have similar functions, although a paucity of data still exists with respect to inflammatory disorders. Eotaxin (CCL11), eotaxin 2 (CCL24), RANTES (CCL5), MCP3 (CCL7), -4 (CCL13) and CCR3 expression were observed in bronchial biopsies from atopic and nonatopic asthmatics (40). In addition, an increased bone marrow pool of CCR3(+) mature and immature eosinophils has been described in subjects with asthma (41). Thus, it appears that CCR3 is substantially involved in the recruitment of inflammatory cells in the allergic response. Confirming this issue, the pretreatment of eosinophils from allergic and eosinophilic donors with a monoclonal antibody to CCR3 blocked chemotaxis and calcium flux induced by all CCR3 ligands (42). These results demonstrated the importance of CCR3 for eosinophil responses.

Although some specific eosinophil function depends on CCR3 activation, other receptors expressed by eosinophils also appear to be functional. Recent studies observed that peripheral blood eosinophils from patients with eosinophilic lung diseases expressed other chemokine receptors in addition to CCR3. It was observed that bronchoalveolar lavage eosinophils from allergic patients had an increase in CXCR4 and a decrease in CCR3 expression (43). These results suggest that CCR3 may be a primary mediator and CXCR4 is cooperatively involved in the eosinophil accumulation at inflamed tissue sites. Initially, CCR3 was 
thought to be specific to eosinophils, but has subsequently been detected on Th 2 cell subsets, as well as basophils, mast cells, neural tissue and airway epithelia. It appears that CCR3 is important for the basal trafficking of eosinophils to the intestinal mucosa but not to the lung. Furthermore, CCR3 may be involved in mast cell homing to epithelial tissues $(44,45)$ as well as leukotriene $\mathrm{C}_{4}$ production by eosinophils and basophils (46).

Other chemokine receptors vary considerably in their expression patterns between leukocyte subsets (Tables 3 and 4). CCR1, CCR5 and CXCR3 are preferentially expressed in Th1 cells, whereas CCR3, CCR4 and CCR 8 seem to be typical of Th2 cells. Likewise, mast cells also express a number of chemokine receptors including, CCR1, CCR2, CCR3, CCR4, CCR5, CCR6, CX3CR1 and XCR1 (47-49). These observations highlight the complexity and difficulty researchers have faced in the functional characterization of chemokines and their receptors.

When examining responses in various cell types, the complexity of the chemokine system becomes readily evident. There are experimental data demonstrating that eotaxin (CCL11) is the most potent eosinophil chemotactic factor. However, additional studies have now demonstrated that other nonCCR3-binding chemokines, including MDC (CCL22), MIP-1ß (CCL4), TCA-3 (CCL1), C10, and TARC (CCL17), can also induce eosinophil activation as well as eosinophil migration. In studies from our laboratories, we have observed that eosinophils elicited from the peritoneum of sensitized mice display additional chemotactic responses to specific CC chemokines, which are absent from peripheral blood eosinophils. We demonstrated that CCR5 and CCR8 ligands MIP13 (CCL4) and TCA-3 (CCL1) were able to induce elicited eosinophils to migrate using in vitro chemotactic assays. Furthermore, the pretreated IL-4- or -TNF- $\alpha$-elicited eosinophils show upregulation of the expression and function of CCR5 and CCR8 (50) (Tables 5 and 6). We also observed that these chemokines were able to induce a dramatic eosinophil peroxidase release, suggesting that MIP$1 B$ (CCL4) and TCA-3 (CCL1) are potent eosinophil activators (Table 6). These studies have been supported by data in CCR8-/mice, where the most significant alterations were decreased eosinophil accumulation and release of eosinophil peroxidase into the bronchoalveolar lavage fluid (51).

Historically, the CXC chemokine receptor expression was thought to be common in neutrophils but not in eosinophils. However, the role of CXC receptor expression in eosinophil function has been described recently. The CXCR3 receptor expression was observed in eosinophils from nonallergic individuals and is up- and downregulated by IL2 and IL-10, respectively. IP-10 (CXCL10) and Mig (CXCL9), via CXCR3, activate

Table 3. CC chemokine receptor expression in leukocytes and structural cells. CCR1 CCR2 CCR3 CCR4 CCR5 CCR6 CCR7 CCR8 CCR9 CCR10 CCR11

\begin{tabular}{|c|c|c|c|c|c|c|c|c|c|c|c|}
\hline Eosinophils & + & + & + & - & + & + & - & + & - & - & - \\
\hline Neutrophils & + & + & + & - & - & - & - & - & - & - & - \\
\hline Mast cells & + & + & + & + & + & + & + & - & - & - & - \\
\hline Macrophages & + & + & - & - & + & - & - & - & + & - & - \\
\hline Lymphocytes & + & + & + & + & + & + & + & + & + & + & + \\
\hline Fibroblasts & - & + & + & - & - & - & - & - & - & + & - \\
\hline Epithelial cells & - & - & + & - & - & + & - & - & - & + & - \\
\hline Endothelial cells & - & + & + & + & - & - & - & - & - & + & - \\
\hline $\begin{array}{c}\text { Airway smooth } \\
\text { muscle cells }\end{array}$ & - & + & - & - & - & - & - & - & - & - & - \\
\hline
\end{tabular}


eosinophils to migrate, release eosinophil cationic protein and induce NF-AT complex nuclear translocation (52).

The functional role of CXCR4 expression in eosinophils was observed to be inducible and SDF-1 $\alpha$ (CXCL12) elicited strong migration comparable to that induced by eotaxin (CCL11). Th2 cytokines such as IL-4 and IL-5 drastically inhibited the expression of CXCR4 (53). These studies provide useful insights into novel mechanisms of action of the CXC chemokines in the pathophysiology of allergic inflammation, including initiation, progression and termination of the eosinophilic processes.

In support for a role for CXCR4, a CXCR4 antagonist (AMD3100) was observed to attenuate allergic lung inflammation and airway hyperreactivity in mice. AMD3100treated animals had reduced airway hyperreactivity, peribronchial eosinophilia and overall inflammatory responses, as well as reduced IL-4 and IL-5 levels (54).

The CXCR3-selective chemokine ligands also may represent an important therapeutic approach to control the allergic processes, since the CXC ligands, IP-10 (CXCL10), Mig (CXCL9) and I-TAC (CXCL11) can act as antagonists of CCR3 and thereby inhibit the infiltration of Th2 cells, in addition to their agonist effects on CXCR3, which lead to attraction of Th1 cells (55). Therefore, although most of the research in allergic asthma has concentrated on the CC family of chemokines, the CXC family also appears to have a distinct function in the overall development and severity of disease.

\section{Conclusion}

Chemokines play an important role in the allergic inflammatory process through the initiation of leukocyte recruitment, activation and regulation of disease severity. Chemokines are very promiscuous and bind to multiple receptors. Therefore, determining the precise function of the individual
Table 4. CXC chemokine receptor expression in leukocytes and structural cells.

\begin{tabular}{|c|c|c|c|c|c|c|}
\hline & CXCR1 & CXCR2 & CXCR3 & CXCR4 & CXCR5 & CXCR6 \\
\hline Eosinophils & - & - & + & + & - & - \\
\hline Neutrophils & + & + & - & + & - & - \\
\hline Mast cells & + & + & - & + & - & - \\
\hline Macrophages & - & - & - & + & - & - \\
\hline Lymphocytes & - & - & + & + & + & + \\
\hline Fibroblasts & - & + & - & - & - & - \\
\hline Epithelial cells & - & - & + & - & - & - \\
\hline Endothelial cells & + & + & + & + & - & - \\
\hline $\begin{array}{c}\text { Airway smooth } \\
\text { muscle cells }\end{array}$ & - & - & + & - & - & - \\
\hline
\end{tabular}

Table 5. CC chemokine receptor expression on eosinophils stimulated with TNF- $\alpha$ or IL-4.

\begin{tabular}{lcccccc} 
Stimulus & \multicolumn{7}{c}{ mRNA receptor expression } \\
\cline { 2 - 7 } & CCR1 & CCR2 & CCR3 & CCR4 & CRR5 & CCR8 \\
\hline Medium (control) & ++ & - & +++ & - & - & - \\
+ TNF- $\alpha$ & +++ & - & +++ & - & ++ & ++ \\
+ IL-4 & + & - & +++ & - & ++ & ++ \\
\hline
\end{tabular}

RT-PCR was used to evaluate mRNA CC chemokine receptor expression. The results are reported as band intensity of mRNA expression as follows: $-=$ no mRNA expression; + = weak mRNA expression; ++ = intermediate mRNA expression; +++ = strong mRNA expression, when compared with control group ß-actin.

Table 6. CC chemokine receptor functional activity (chemotactic activity, EPO release and $\mathrm{Ca}^{2+}$ flux activity) on eosinophils (Eos) stimulated with TNF- $\alpha$ or IL-4.

\begin{tabular}{|c|c|c|c|c|c|}
\hline \multirow[t]{2}{*}{ Stimulus } & \multicolumn{3}{|c|}{ Chemotactic activity } & EPO release & $\mathrm{Ca}^{2+}$ flux \\
\hline & Eos+Medium & Eos+IL-4 & Eos+TNF- $\alpha$ & Eos+Medium & Eos+Medium \\
\hline
\end{tabular}

MIP-1 $\alpha$ (CCR 1$)$

MCP-1 (CCR2)

Eotaxin (CCR3)

MDC (CCR4)

TCA-3 (CCR8)
MIP-1ß (CCR5)

++
-
++
-
-
-

$++$

$++$

$-$

$-$

$\begin{array}{cc}- & ++ \\ - & \\ +++ & ++ \\ - & \\ ++ & + \\ ++ & +\end{array}$

$++++$

+++
-
++
-
++
++

Results are reported as the following parameters: - = no chemotactic activity, EPO release or $\mathrm{Ca}^{2+}$ flux; $+=$ weak chemotactic activity, EPO release or $\mathrm{Ca}^{2+}$ flux; $++=$ intermediate chemotactic activity, EPO release or $\mathrm{Ca}^{2+}$ flux; $+++=$ strong chemotactic activity, EPO release or $\mathrm{Ca}^{2+}$ flux, when compared with control (nonstimulated eosinophils). $E P O=$ eosinophil peroxidase. 
chemokines and receptors will be essential to the definition of the correct targets. The analysis of the function of eosinophils and their chemokine receptors during inflammation continues to be a good approach to understanding the determinants of asthma severity and developing novel therapies. Blocking the infiltration of eosinophils and other cell populations by manipulation of chemokine-mediated responses may have a large impact on disease severity.

\section{References}

1. Luster AD (1998). Chemokines-chemotactic cytokines that mediate inflammation. New England Journal of Medicine, 338: 436-445.

2. Lukacs NW, Oliveira SHP \& Hogaboam CM (1999). Chemokines and asthma: redundancy of function or a coordinated effort? Journal of Clinical Investigation, 104: 995-999.

3. Rollins BJ (1997). Chemokines. Blood, 90: 909-928.

4. Furie MB \& Randolph GJ (1995). Chemokines and tissue injury. American Journal of Pathology, 146: 1287-1301.

5. Baggiolini M \& Dahinden CA (1994). CC chemokines in allergic inflammation. Immunology Today, 15: 127-133.

6. Strieter RM, Standiford TJ, Huffnagle GB, Colletti LM, Lukacs NW \& Kunkel SL (1996). "The good, the bad, and the ugly." The role of chemokines in models of human disease. Journal of Immunology, 156: 3583-3586.

7. Christopherson 2 nd K \& Hromas R (2001). Chemokine regulation of normal and pathologic immune responses. Stem Cells, 19: 388-396.

8. Zlotnik A \& Yoshie O (2000). Chemokines: a new classification system and their role in immunity. Immunity, 12: 121-127.

9. Thelen M (2001). Dancing to the tune of chemokines. Nature Immunology, 2: 129-134.

10. Neptune ER \& Bourne HR (1997). Receptors induce chemotaxis by releasing the betagamma subunit of $\mathrm{Gi}$, not by activating $\mathrm{Gq}$ or $\mathrm{Gs}$. Proceedings of the National Academy of Sciences, USA, 94: 1448914494.

11. Neptune ER, Liri T \& Bourne HR (1999). Galphai is not required for chemotaxis mediated by Gi-coupled receptors. Journal of Biological Chemistry, 274: 2824-2828.

12. Baggiolini M, Dewald B \& Moser B (1997). Human chemokines. An update. Annual Review of Immunology, 15: 675-705.

13. Li Z, Jiang H, Xie W, Zhang Z, Smrcka AV \& Wu D (2000). Roles of PLC-beta2 and -beta3 and PI3Kgamma in chemoattractant-mediated signal transduction. Science, 287: 1046-1049.

14. Ward SG \& Westwick J (1998). Chemokines: understanding their role in T lymphocyte biology. Biochemical Journal, 333: 457-470.

15. Ward SG, Bacon KB \& Westwick J (1998). Chemokines and T lymphocytes: more than an attraction. Immunity, 8: 1-11.

16. Curnock AP, Logan MK \& Ward SG (2002). Chemokine signaling: pivoting around multiple phosphoinositide 3-kinases. Immunology, 105: 125-136.

17. Krymskaya VP, Penn RB, Orsini MJ, Scott PH, Plevin RJ, Walker TR, Eszterhas AJ, Amrani Y, Chilvers ER \& Panettieri Jr RA (1999). Phosphatidylinositol 3-kinase mediates mitogen-induced human airway smooth muscle cell proliferation. American Journal of Physiology, 277 (1 Part 1): L65-L78.

18. Sasaki T, Irie-Sasaki J, Horie $Y$ et al. (2000). Colorectal carcinomas in mice lacking the catalytic subunit of PI(3)Kgamma. Nature, 406: 897902.

19. Hirsch E, Wymann MP, Patrucco E, Tolosano E, Bulgarelli-Leva G,
Marengo S, Rocchi M \& Altruda F (2000). Analysis of the murine phosphoinositide 3-kinase gamma gene. Gene, 256: 69-81.

20. Hofmann C, Dichmann S, Zimpfer U, Czech W, Herouy Y, Wagner E \& Norgauer J (2000). Metabolism and function of 3-D-phosphorylated phosphoinositides in C5a-stimulated eosinophils. Biochemical and Biophysical Research Communications, 269: 816-821.

21. Kampen GT, Stafford S, Adachi T, Jinquan T, Quan S, Grant JA, Skov PS, Poulsen LK \& Alam R (2000). Eotaxin induces degranulation and chemotaxis of eosinophils through the activation of ERK2 and p38 mitogen-activated protein kinases. Blood, 95: 1911-1917.

22. Adachi T, Choudhury BK, Stafford S, Sur S \& Alam R (2000). The differential role of extracellular signal-regulated kinases and p38 mitogen-activated protein kinase in eosinophil functions. Journal of Immunology, 165: 2198-2204.

23. Djukanovic R, Wilson JW, Britten KM, Wilson SJ, Walls AF, Roche WR, Howarth PH \& Holgate ST (1990). Quantitation of mast cells and eosinophils in the bronchial mucosa of symptomatic atopic asthmatics and healthy control subjects using immunohistochemistry. American Review of Respiratory Disease, 142: 863-871.

24. Bradley BL, Azzawi M, Jacobson M, Assoufi B, Collins JV, Irani AM, Schwartz LB, Durham SR, Jeffery PK \& Kay AB (1991). Eosinophils, T-lymphocytes, mast cells, neutrophils, and macrophages in bronchial biopsy specimens from atopic subjects with asthma: comparison with biopsy specimens from atopic subjects without asthma and normal control subjects and relationship to bronchial hyperresponsiveness. Journal of Allergy and Clinical Immunology, 88: 661674.

25. Kay AB \& Corrigan CJ (1992). Asthma. Eosinophils and neutrophils. British Medical Bulletin, 48: 51-64.

26. Kay AB, Barata L, Meng Q, Durham SR \& Ying S (1997). Eosinophils and eosinophil-associated cytokines in allergic inflammation. International Archives of Allergy and Immunology, 113: 196-199.

27. Kitayama J, Mackay CR, Ponath PD \& Springer TA (1998). The C-C chemokine receptor CCR3 participates in stimulation of eosinophil arrest on inflammatory endothelium in shear flow. Journal of Clinical Investigation, 101: 2017-2024.

28. Smith RS, Smith TJ, Blieden TM \& Phipps RP (1997). Fibroblasts as sentinel cells. Synthesis of chemokines and regulation of inflammation. American Journal of Pathology, 151: 317-322.

29. Hogaboam CM, Smith RE \& Kunkel SL (1998). Dynamic interactions between lung fibroblasts and leukocytes: implications for fibrotic lung disease. Proceedings of the Association of American Physicians, 110: 313-320.

30. Chung KF (2000). Airway smooth muscle cells: contributing to and regulating airway mucosal inflammation? European Respiratory Journal, 15: 961-968.

31. Kita H \& Gleich GJ (1996). Chemokines active on eosinophils: potential roles in allergic inflammation. Journal of Experimental Medicine, 
183: 2421-2426.

32. Lukacs NW, Standiford TJ, Chensue SW, Kunkel RG, Strieter RM \& Kunkel SL (1996). C-C chemokine-induced eosinophil chemotaxis during allergic airway inflammation. Journal of Leukocyte Biology, 60: 573-578.

33. Griffiths-Johnson DA, Collins PD, Jose PJ \& Williams TJ (1997). Animal models of asthma: role of chemokines. Methods in Enzymology, 288: 241-266.

34. Gutierrez-Ramos JC, Lloyd C, Kapsenberg ML, Gonzalo JA \& Coyle AJ (2000). Non-redundant functional groups of chemokines operate in a coordinate manner during the inflammatory response in the lung. Immunological Reviews, 177: 31-42.

35. Gonzalo JA, Lloyd CM, Kremer L, Finger E, Martinez-A C, Siegelman MH, Cybulsky M \& Gutierrez-Ramos JC (1996). Eosinophil recruitment to the lung in a murine model of allergic inflammation. The role of T cells, chemokines, and adhesion receptors. Journal of Clinical Investigation, 98: 2332-2345.

36. Gonzalo JA, Lloyd CM, Wen D et al. (1998). The coordinated action of $\mathrm{CC}$ chemokines in the lung orchestrates allergic inflammation and airway hyperresponsiveness. Journal of Experimental Medicine, 188: 157-167.

37. Gonzalo JA, Pan Y, Lloyd CM et al. (1999). Mouse monocyte-derived chemokine is involved in airway hyperreactivity and lung inflammation. Journal of Immunology, 163: 403-411.

38. Lukacs NW, Strieter RM, Warmington K, Lincoln P, Chensue SW \& Kunkel SL (1997). Differential recruitment of leukocyte populations and alteration of airway hyperreactivity by $\mathrm{C}$-C family chemokines in allergic airway inflammation. Journal of Immunology, 158: 43984404.

39. Jose PJ, Griffiths-Johnson DA, Collins PD, Walsh DT, Mogbel R, Totty NF, Truong O, Hsuan JJ \& Williams TJ (1997). Eotaxin: a potent eosinophil chemoattractant cytokine detected in a guinea pig model of allergic airway inflammation. Journal of Experimental Medicine, 179: 881-887.

40. Ying S, Meng Q, Zeibecoglou K, Robinson DS, Macfarlane A, Humbert M \& Kay AB (1999). Eosinophil chemotactic chemokines (eotaxin, eotaxin-2, RANTES, monocyte chemoattractant protein-3 (MCP-3), and MCP-4), and C-C chemokine receptor 3 expression in bronchial biopsies from atopic and nonatopic (intrinsic) asthmatics. Journal of Immunology, 163: 6321-6329.

41. Zeibecoglou K, Ying S, Yamada T, North J, Burman J, Bungre J, Meng $\mathrm{Q}$, Kay $A B$ \& Robinson DS (1999). Increased mature and immature CCR3 messenger RNA+ eosinophils in bone marrow from patients with atopic asthma compared with atopic and nonatopic control subjects. Journal of Allergy and Clinical Immunology, 103 (1 Part 1): 99-106.

42. Heath H, Qin S, Rao P, Wu L, Larosa G, Kassam N, Ponath PD \& Mackay CR (1997). Chemokine receptor usage by human eosinophils. The importance of CCR3 demonstrated using an antagonistic monoclonal antibody. Journal of Clinical Investigation, 99: 178-184.

43. Nagase H, Kudo K, Izumi S, Ohta K, Kobayashi N, Yamaguchi M,
Matsushima K, Morita Y, Yamamoto K \& Hirai K (2001). Chemokine receptor expression profile of eosinophils at inflamed tissue sites: Decreased CCR3 and increased CXCR4 expression by lung eosinophils. Journal of Allergy and Clinical Immunology, 108: 563-569.

44. Humbles AA, Lu B, Friend DS, Okinaga S, Lora J, Al-Garawi A, Martin TR, Gerard NP \& Gerard C (2002). The murine CCR3 receptor regulates both the role of eosinophils and mast cells in allergen-induced airway inflammation and hyperresponsiveness. Proceedings of the National Academy of Sciences, USA, 99: 1479-1484.

45. Ma W, Bryce PJ, Humbles AA, Laouini D, Yalcindag A, Alenius $H$, Friend DS, Oettgen HC, Gerard C \& Geha RS (2002). CCR3 is essential for skin eosinophilia and airway hyperresponsiveness in a murine model of allergic skin inflammation. Journal of Clinical Investigation, 109: 621-628.

46. Bandeira-Melo C, Phoofolo M \& Weller PF (2001). Extranuclear lipid bodies, elicited by CCR3-mediated signaling pathways, are the sites of chemokine-enhanced leukotriene C4 production in eosinophils and basophils. Journal of Biological Chemistry, 276: 22779-22787.

47. Bonecchi R, Bianchi G, Bordignon PP et al. (1998). Differential expression of chemokine receptors and chemotactic responsiveness of type 1 $\mathrm{T}$ helper cells (Th1s) and Th2s. Journal of Experimental Medicine, 187: 129-134.

48. Sallusto F, Mackay CR \& Lanzavecchia A (1997). Selective expression of the eotaxin receptor CCR3 by human T helper 2 cells. Science, 277 2005-2007.

49. Oliveira SH \& Lukacs NW (2001). Stem cell factor and IgE-stimulated murine mast cells produce chemokines (CCL2, CCL17, CCL22) and express chemokine receptors. Inflammation Research, 50: 168-174.

50. Oliveira SH, Lira S, Martinez-A C, Wiekowski M, Sullivan L \& Lukacs NW (2002). Increased responsiveness of murine eosinophils to MIP-1beta (CCL4) and TCA-3 (CCL1) is mediated by their specific receptors, CCR5 and CCR8. Journal of Leukocyte Biology, 71: 1019-1025.

51. Chensue SW, Lukacs NW, Yang T-Y et al. (2001). Aberrant in vivo T helper type 2 cell response and impaired eosinophil recruitment in CC chemokine receptor 8 knockout mice. Journal of Experimental Medicine, 193: 573-584.

52. Jinquan $\mathrm{T}$, Jing $\mathrm{C}$, Jacobi $\mathrm{HH}$ et al. (2000). CXCR3 expression and activation of eosinophils: role of IFN-gamma-inducible protein-10 and monokine induced by IFN-gamma. Journal of Immunology, 165: 15481556

53. Nagase $H$, Miyamasu M, Yamaguchi M, Fujisawa T, Ohta K, Yamamoto K, Morita Y \& Hirai K (2000). Expression of CXCR4 in eosinophils: functional analyses and cytokine-mediated regulation. Journal of Immunology, 164: 5935-5943.

54. Lukacs NW, Berlin A, Schols D, Skerlj RT \& Bridger GJ (2002). AMD3100, a CXCR4 antagonist, attenuates allergic lung inflammation and airway hyperreactivity. American Journal of Pathology, 160: 1353-1360.

55. Loetscher P, Pellegrino A, Gong JH, Mattioli I, Loetscher M, Bardi G, Baggiolini M \& Clark-Lewis I (2001). The ligands of CXC chemokine receptor 3, I-TAC, Mig, and IP10, are natural antagonists for CCR3. Journal of Biological Chemistry, 276: 2986-2991. 